\title{
Thermal and catalytic methods used for destruction of chemical warfare agents
}

\author{
J. Nawała ${ }^{1}$ [D P. Jóźwik ${ }^{1}$ S. Popiel ${ }^{1}$
}

Received: 5 June 2018 / Revised: 15 February 2019 / Accepted: 8 April 2019 / Published online: 22 April 2019

(c) The Author(s) 2019

\begin{abstract}
The decontamination of chemical warfare agents (CWAs) from structures, environmental media and even personnel has become an area of particular interest in recent years due to increased homeland security concerns. This article reviews applications of catalytic methods used for decontamination of CWAs. Most attention was given to the following methods: thermocatalysis, photocatalysis and enzyme catalysis among the many methods of catalytic CWA decomposition. Unfortunately, there are not enough data obtained with real CWAs due to the difficulty in handling, so we have described also data available for CWAs simulants. These methods can be useful for decontamination systems that can reduce the damage caused by possible terrorism.
\end{abstract}

Keywords Chemical warfare agents $\cdot$ Chemical warfare agents disposal $\cdot$ Enzyme catalysis · Thermocatalysis .

Photocatalysis · Decontamination

\section{Introduction}

International negotiations on the implementation of the Treaty on the Prohibition of Chemical Weapons began as part of the UN Disarmament Conference in 1980. On November 30, 1992, the UN General Assembly adopted the Convention on the Prohibition of Chemical Weapons by way of resolution A/ RES/47/391. The adopted text of the Convention was presented for signature in January 1993 in Paris (The Convention on the Prohibition of the Development, Production 1993). In April 1997, when the 65th State ratified the Convention on "Prohibition of researching, production, storage and use of chemical weapons and destruction of its stocks," it entered into force and its abbreviated name is Chemical Weapon Convention-CWC.

The established document prohibits all Member States from carrying out research, production, storage and use of chemical weapons, and obliges to disclose chemical weapons supplies and their destruction. The fact that not all countries in the world have signed this convention or have signed but still did not ratify it may raise concerns.

Editorial responsibility: Mohamed F. Yassin.

\section{J. Nawała}

jakub.nawala@wat.edu.pl

1 Faculty of Advanced Technology and Chemistry, Military University of Technology, Warsaw, Poland
Despite the implementation of this document, the problem related to chemical weapons is still very important, mainly due to the need to dispose of chemical weapons (CWA) supplies (Johnson-Winegar 2001), as well as the ever-growing threat of terrorist attacks (Bismuth et al. 2004). An example of this type of use of chemical weapon was the terrorist attack of 20 March 1995 in Japan, where the release of sarin resulted in: 12 fatalities, 54 seriously injured, 980 with medium injuries and 5500 who need medical attention (Bismuth et al. 2004; Schecter and Fry 2005). Chemical weapon can also be used during warfare; an example of such action is the use of sarin against civilians in Syria (Henderson 2015). An extremely important issue is also mentioned neutralization of supplies of chemical weapons sunk in the seas after World War II. For example, in the years 1922-1945, around 79 thousand tons of sulfur mustard was produced in the world (Popiel et al. 2014a, b; Nawała et al. 2016). At present, about 70 years after the sinking in the Baltic Sea containers, in which there is chemical weapon, sometimes they are unsealed, which of course causes pollution of the environment. It also happens that these containers are caught by fishermen or thrown on the beach by sea waves (Mazurek et al. 2001).

Decontamination is a process of removal or neutralization of CWA from various surfaces, including the surfaces of contaminated equipment and weapons. In case of decontamination of people and equipment, classical methods can be easily replaced or modified using catalytic methods, which can include advanced oxidation techniques (Popiel et al. 
2005) or enzymatic catalysis (Popiel et al. 2010; Popiel and Nawała 2013). However, these methods cannot be used to neutralize chemical warfare agents in the air.

The most commonly used methods for the removal of toxic substances from the air are still filters containing adsorbents such as activated carbon, silica gel and active alumina or for biological agents high-efficiency nonwoven filters-HEPA (high-efficiency particulate air) and ULPA (ultra-low particulate air) filters. The main drawback of this method of air purification is filtering and not deactivation of dangerous compounds, which after the filtration process still remain intact, adsorbed in filters. In the case of filters, the negative impact of environmental factors (including moisture and heat) on their effectiveness (especially in relation to chemical substances) is also quickly visible, as well as limited working time.

An alternative to the described classic air cleaning systems may be devices with thermoactive elements made of thermocatalytically active metallic materials. It was proved (Jóźwik et al. 2010) that their surface catalytic activity was demonstrated with respect to sulfur and sulfur mustard. The proposed new solutions significantly reduce the problems associated with the storage and servicing of systems with activated carbon sensitive to the presence of water vapor.

The development and finding new, better and more modern methods of elimination of contaminations, including chemical warfare agents, should be based on the latest scientific achievements. The available literature shows that neither perfect decontamination methods nor perfect disinfectants have been developed so far. Neutralization of CWA from the point of view of the mechanism is usually a complex and difficult process.

Another important aspect is the efficient and quick cleaning of contaminated air from large enclosed spaces such as shopping centers, office buildings or metro stations. One of the oldest methods is to pump it through filters containing activated carbon, but this is a temporary solution, because, as already mentioned, it does not solve the problem entirely. Activated carbon only adsorbs toxic substances on its surface. During desorption, toxic substances are released from the surface of activated carbon and the problem may appear again. The current state of knowledge allows two techniques, the use of which will result in the decontamination of polluted air. These include photo- and thermocatalysis. In the first case, catalysts exposed to UV radiation will be used and in the second case thermally activated catalysts.

The aim of the presented work was to describe, on the basis of the most recent literature data, various catalytic methods that can be used to remove contamination caused by the release of chemical warfare agents (CWA) into the environment as a result of failure or conscious actions of people, e.g., terrorists.

\section{Chemical warfare agents}

Chemical warfare agents are toxic chemical compounds whose chemical and physical properties allow their military application. The most important feature of CWA is their lethal or harmful effect on living organisms (humans, animals, plants).

Sulfur mustard and sarin represent two groups of toxic substances. Sarin is an organophosphorus compound belonging to the group of the most dangerous poisons, i.e., to nerve agents group which possess paralyzing properties. Sulfur mustard, in turn, belongs to type of vesicant compounds which cause blistering of the skin and mucous membranes on contact. These two compounds were chosen due to the fact that they are the most popular chemical warfare agents (Bartelt-Hunt et al. 2006). It is not without significance that they can be relatively easily obtained (Ledgard 2012). It is worth noting that large amounts of sulfur mustard are dumped in the Baltic Sea and other sea areas (National Research Council 1984), and sarin can be used in military, criminal (National Research Council 1996; Pearson and Magee 2002) or terrorist (Okumura et al. 2005) actions.

\section{Sulfur mustard}

Sulfur mustard (HD) is a typical chemical warfare agent from the stinging group. During the First World War, it was used on the battlefield on a mass scale. After the not very successful use of chlorine and phosgene (these gases were too easy to detect with sense of smell, so after detection-it was possible to put on a gas mask in time), in the final phase of the mustard gas was introduced. Mustard gas is relatively simple in production and can therefore be the so-called first choice measure, if a country decides, despite the aforementioned CWC convention, to conduct a war with the use of chemical weapons.

Pure sulfur mustard is a colorless liquid with a barely perceptible odor. The technical product, on the other hand, has a brown color and smell of mustard, which is why it was called a mustard gas. HD is a compound that easily penetrates through various materials, and only bromobutyl rubber is impermeable to sulfur mustard for some time (up to $24 \mathrm{~h}$ ) (Dubey et al. 2002). Mustard gas is slightly soluble in water, at a temperature of $10{ }^{\circ} \mathrm{C}$ its solubility is $0.6 \mathrm{~g} / \mathrm{L}$, while it is very soluble in organic solvents. It is also a good solvent for other war toxic agents (Malhotra et al. 1999).

Due to the high toxicity and difficulty in obtaining research permits for pure sulfur mustards, which result from the CWC convention, its simulants are used for research works. One of the simplest simulants of sulfur mustard is dibutyl sulfide; however, the most popular simulant is 2-chloroethyl ethyl sulfide (CEES) (Verma et al. 2015, 2016; Liu et al. 2015; Li et al. 2014). 
CEES is used, instead of mustard gas, in research on detection, labeling, reaction mechanisms and decontamination processes. The comparison of the toxic action of sulfur mustard with its simulator should take into account all possible routes of absorption into the human body. LD50 doses (causing death of half the population) of sulfur mustard and CEES for mice depending on the absorption path are presented in Table 1. In the case of sulfur mustard, intraperitoneal (i.p.) and percutaneous (p.c.) absorption is the most toxic way of absorption. In the case of CEES, however, it is intraperitoneal (i.p.) and subcutaneous absorption (s.c.). After exceeding the $\mathrm{LD}_{50}$ dose for CEES, the death occurred within 1-2 days, whereas if the dose was exceeded by sulfur mustard, the death of the individuals occurred even after more than 6 days.

Both sulfur mustard and CEES cause oxidative stress, but their toxic properties are different. In the case of sulfur mustard, percutaneous absorption (p.c.) is more dangerous than subcutaneous (s.c.) or oral (p.o.).This is most likely due to different metabolic pathways. However, it is completely different in the case of CEES. The use of CEES as a simulant of sulfur mustard is justified in many experiments, but may not be appropriate in the case of seeking an antidote for sulfur mustard, since the toxic properties of sulfur mustard and CEES differ substantially.

\section{Sarin}

The most dangerous, chemical warfare agents are organophosphorus compounds with a paralytic and convulsive action. Their development is mainly in the interwar period.

Sarin (GB) is one of the more accessible CWAs, which makes it particularly dangerous. It is owned by many states and rich terrorist organizations. The GB manufacturing process is also relatively simple. The only problem is obtaining precursors that have strong corrosive properties $(\mathrm{Li}$ et al. 2000). Sarin can be obtained from common substances such as pesticides and compounds used for wood impregnation in order to ensure its non-flammability.

Sarin is a colorless and almost odorless liquid with a boiling point of $147.3{ }^{\circ} \mathrm{C}$. At this temperature occurs its

Table 1 Comparison of $\mathrm{LD}_{50}$ dose of mustard gas (HD) and chloroethyl ethyl sulfide (CEES) for a mouse with relationship to way of penetrating toxic substance into organism

\begin{tabular}{lcl}
\hline Route & $\mathrm{LD}_{50} \mathrm{HD}(\mathrm{mg} / \mathrm{kg})$ & $\begin{array}{l}\mathrm{LD}_{50} \\
\mathrm{CEES} \\
(\mathrm{mg} / \mathrm{kg})\end{array}$ \\
\hline Through the skin (p.c.) & 9.7 & 1425 \\
Subcutaneous (s.c.) & 13.5 & 100 \\
Orally (p.o.) & 19.3 & 566 \\
Intraperitoneally (i.p.) & 4.8 & 17.7 \\
\hline
\end{tabular}

partial decomposition. Sarin is a substance with a relatively high vapor pressure, and at $20{ }^{\circ} \mathrm{C}$, it is $1.48 \mathrm{~mm} \mathrm{Hg}$. The volatility of sarin at the same temperature is $11.3 \mathrm{mg} / \mathrm{l}$. Its vapors are about 4.8 times heavier than air, while the vapor density is not much lower than air density and at $20^{\circ} \mathrm{C}$ and amounts to $11,102 \mathrm{~kg} / \mathrm{m}^{3}$. Sarin is highly soluble in organic solvents (e.g., in alkanols, esters, halide alcohols, benzene series hydrocarbons) and in other chemical warfare agents (e.g., sulfur mustard) mixes with water in every ratio. Sarin vapors adsorb well in porous materials like concrete, brick, wood and textiles (Marrs et al. 2007).

In the case of sarin, its most popular simulant is dimethyl methylphosphonate (DMMP) (Shen et al. 2016; Dumlao et al. 2016; Verma et al. 2016; Powroźnik et al. 2015; Mitchell et al. 2014). DMMP is used as a model compound for the study of decontamination processes, reaction mechanisms, adsorption and desorption of compounds with paralytic and convulsive action, including sarin. DMMP is included in the chemical weapons convention in list 2 , indicating that it is toxic enough to be used as a chemical weapon or used as a precursor to other more toxic substances. Table 2 compares the toxic properties of DMMP and sarin.

\section{Thermal methods used to neutralize chemical warfare agents}

\section{Combustion}

Combustion is an environmentally safe method of disposal of toxic substances, which has the highest percentage share of all methods used to destroy hazardous substances (Review and Evaluation of the Army Chemical Stockpile Disposal Program 1996). An American program for chemical weapon destruction based on this method was used in 1969-1976 to destroy almost 3000 tons of sulfur mustard in the Rocky Mountains as part of the Chemical Agent Munitions Disposal System at the Tooele Army Ammunition Plant and 19,000 missiles and 14,000 rockets filled with paralytic and convulsive agents under the "Johnston Atoll Chemical Disposal System (JADACS)" at Johnston Pacific Atoll (National Research Council 1984). The experience gained during the

Table 2 Comparison of toxic properties $\left(\mathrm{LD}_{50}\right)$ of sarin and dimethyl methyl phosphate (DMMP)

\begin{tabular}{lll}
\hline Type of organism and rout & Sarin & DMMP \\
\hline Mouse, orally & - & $6.81 \mathrm{mg} / \mathrm{kg}$ \\
Human, orally & $28 \mathrm{mg} / \mathrm{kg}$ & - \\
Rat, orally & $1.06 \mathrm{mg} / \mathrm{kg}$ & $8.21 \mathrm{mg} / \mathrm{kg}$ \\
Rat, intravenous injection & $0.045 \mathrm{mg} / \mathrm{kg}$ & - \\
Mouse, intravenous injection & $0.07-0.113 \mathrm{mg} / \mathrm{kg}$ & - \\
\hline
\end{tabular}


JADACS system was used to construct a second-generation chemical weapons combustion installation, which work was divided into three stages: (1) separation of chemical warfare agents, explosives (Committee on Review and Evaluation of the Army Chemical Stockpile Disposal Program 1996) and other materials contained in the missiles (waste) to prepare for combustion; (2) combustion warfare agents, explosives and the waste thermal decomposition of metal parts and missile storage containers; (3) protection and monitoring of the gaseous stream of combustion products, analysis and destruction of liquid and solid waste. As part of the first stage, four groups of contaminated materials with different physical properties were created. Their controlled separation allows optimal adjustment of the combustion conditions for each group, which greatly simplifies the destruction process. The individual groups of materials are directed directly to the appropriate furnaces: liquid toxic agents to the furnace, in which liquids are disposed of (liquid incinerator-LIC); explosives to the furnace in which the explosive materials are destroyed (deactivation furnace-DFS); metal parts to the furnace intended for the combustion of metal parts of bullets and bombs (metal parts furnace-MPF); waste to the furnace in which different types of waste are destroyed (Dunnage incinerator-DUN).

CWAs in a liquid form, separated from ammunition and containers, are introduced into the furnace, where a two-stage combustion process occurs at a temperature of $1480{ }^{\circ} \mathrm{C}$. Initially, CWA is sprayed by a special nozzle and then mixed with air. In addition, an auxiliary fuel is introduced to allow the combustion temperature to be maintained above $1400{ }^{\circ} \mathrm{C}$. The resulting gases are sent through the pipes to the most important element of the combustion system, which is the afterburner, where natural gas is used: propane or diesel. This solution eliminates the risk of penetration of combustion intermediates or CWA residues into the system reducing pollution, where the temperature is maintained at a level higher than $1090{ }^{\circ} \mathrm{C}$ (Committee on Review and Evaluation of the Army Chemical Stockpile Disposal Program 1996).

The products of complete combustion of organic compounds containing carbon, hydrogen and oxygen atoms are water vapor and carbon dioxide. If the organic compounds contain additionally fluorine, chlorine, nitrogen, phosphorus and/or sulfur atoms, we can add additional products to the combustion products: hydrogen fluoride in the case of sarin, nitrogen dioxide in the case of a Tabun and VX compound, phosphorus pentoxide in the case of sarin, Tabun and VX compound, and sulfur dioxide and hydrogen chloride in the case of sulfur mustard. The equations for the combustion reaction of selected toxic agents are shown in Fig. 1.

Due to the very high temperature as well as thermal properties of the entire system, such combustion is a very safe and effective method of destroying most CWA. The exception is chemical warfare agents with an arsenic atom in the structure (e.g., lewisites) for which combustion causes the penetration of poisonous organo-arsenic compounds into the atmosphere (Petrov et al. 2006).

Research on improving the CWA combustion method is still ongoing. One of the works on this issue was devoted to the study of the kinetic model of DMMP decomposition in the hydrogen-oxygen flame. The main elements of the research system were: low-pressure combustion chamber, sampling system and ion mobility spectrometer. In addition, a flat stainless steel burner with a diameter of six centimeters was installed, placed in a shield through which argon flowed. The flow of oxygen, hydrogen and argon was controlled by means of a flow regulator. DMMP was added to the argon using a dropping funnel and then mixed with oxygen and hydrogen in the collector. Due to the very low vapor pressure $(0.46 \mathrm{~mm}$ $\mathrm{Hg}$ ), DMMP at $25^{\circ} \mathrm{C}$, the collector and the dropping funnel were continuously heated (Petrov et al. 2006). Combustion of DMMP in a hydrogen-oxygen flame leads to many products such as $\mathrm{H}_{2} \mathrm{CO}_{3}, \mathrm{CH}_{3} \bullet, \mathrm{CH}_{3} \mathrm{OH}, \mathrm{CH}_{3} \mathrm{O}, \mathrm{HOPO}, \mathrm{HOPO}_{2}$.

\section{Pyrolysis}

Pyrolysis is a type of thermolysis defined as a degradation process occurring under the influence of high temperature. The chemical technology for pyrolysis is the processes carried out without contact with oxygen and other oxidants.

One of the possibilities of thermal decomposition of sulfur mustard is the pyrolysis reaction under reduced pressure. Laboratory tests have confirmed that phosgene, diphosgene and chloropicrin are also degraded as a result of this process (Battin-Leclerc et al. 2000).

The sulfur mustard pyrolysis reaction was carried out under nitrogen and air, in which the initial pressure was $16.67 \mathrm{kPa}$ and the pressure of nitrogen was equal to $13.33 \mathrm{kPa}$. The process was carried out at a temperature ranging from 300 to $500{ }^{\circ} \mathrm{C}$ (Glukhovtsev and Bach 1998). During the analysis of the sulfur mustard pyrolysis process, it was found that at $450^{\circ} \mathrm{C}$ the amount of substrate was 100 times lower than at $300{ }^{\circ} \mathrm{C}$. Therefore, the authors of the work (Glukhovtsev and Bach 1998) showed that at $450{ }^{\circ} \mathrm{C}$ sulfur mustard was converted at the level of $99 \%$. The main products of sulfur mustard pyrolysis were ethylene and vinyl chloride. The remaining products are methane, ethane and acetylene and in the trace amounts, propane.

During the pyrolysis of sulfur mustard at $450{ }^{\circ} \mathrm{C}$ and the initial pressure of less than $3.33 \mathrm{kPa}$, only conversion at the

1) $2\left(\mathrm{ClCH}_{2} \mathrm{CH}_{2}\right)_{2} \mathrm{~S}+13,5 \mathrm{O}_{2} \rightarrow 8 \mathrm{CO}_{2}+6 \mathrm{H}_{2} \mathrm{O}+4 \mathrm{HCl}+2 \mathrm{SO}_{2}$

2) $2\left(\mathrm{CH}_{3}\right)_{2} \mathrm{CHO}\left(\mathrm{CH}_{3}\right) \mathrm{POF}+13 \mathrm{O}_{2} \rightarrow \mathrm{P}_{2} \mathrm{O}_{5}+8 \mathrm{CO}_{2}+9 \mathrm{H}_{2} \mathrm{O}+2 \mathrm{HF}$

3) $2 \mathrm{C}_{11} \mathrm{H}_{26} \mathrm{NO}_{2} \mathrm{PS}+38.5 \mathrm{O}_{2} \rightarrow 22 \mathrm{CO}_{2}+26 \mathrm{H}_{2} \mathrm{O}+\mathrm{P}_{2} \mathrm{O}_{5}+2 \mathrm{SO}_{2}+2 \mathrm{NO}$

Fig. 1 The scheme of burn reaction of selected chemical warfare agents: (1) mustard gas, (2) sarin, (3) VX gas 
level of $60 \%$ (Glukhovtsev and Bach 1998) was observed. Under these operating conditions, other unidentified reaction products were also observed in addition to mentioned light organic products.

The available tests show that other decomposition products may also be obtained during the pyrolysis of sulfur mustard, which may include carbon disulfide, 1,2-dichloroethane, thiophene and methylthiophene (Faragher et al. 1928; Wagner et al. 1999; Battin-Leclerc et al. 2000).

\section{Thermocatalysis}

In the above-mentioned work, the idea of using a thermocatalyst for BST destruction is applied to surface-active powder catalysts or metallic bands allowing the decomposition of these compounds.

In the case of CEES adsorption on the surface of $\mathrm{TiO}_{2}$ in the anatase and rutile form, CEES thermal desorption takes place in the temperature range from 2 to $127^{\circ} \mathrm{C}$ for an activation energy of $105 \mathrm{~kJ} / \mathrm{mol}$. The molecules of this compound can be oxidized both by $\mathrm{Ti}-\mathrm{OH}$ groups from anatase and rutile and by oxygen from the crystallographic lattice $\mathrm{TiO}_{2}$. The attack on the $\mathrm{C}-\mathrm{S}$ bond leads to the formation of ethoxy and chloroethoxy groups. At temperatures around $300{ }^{\circ} \mathrm{C}$, these groups are further oxidized to $\mathrm{CO}_{2}$ and $\mathrm{CO}_{3}$, which are then adsorbed on the surface of titanium oxide (IV). At about $325^{\circ} \mathrm{C}$, oxygen reactions (called lattice oxygen) are observed. However, when heating in a vacuum at a temperature of approx. $625{ }^{\circ} \mathrm{C}$ on the surface of $\mathrm{TiO}_{2}$ substrates and oxidation reaction products are no longer observed (Thompson et al. 2004).

Due to the lack of publications regarding the thermal decomposition of sarin as well as other chemical warfare agents from the group of paralytic-convulsive compounds, this part of the work describes the results of tests on the imitation sarin-dimethyl methylphosphonate (DMMP).

Ma et al. (2000) examined the thermal distribution of DMMP on the surface of copper clusters and on a thin layer of copper deposited on the surface of $\mathrm{TiO}_{2}$. Dimethyl methylphosphonate was introduced into the reaction chamber as a liquid so that the resulting concentration of its vapors was maximal to provide a saturated vapor mixture in the reaction zone. The surface of $\mathrm{TiO}_{2}$ has been coated with copper layers at a rate of 0.5-1.5 monolayer per minute using an Oxford Research sprayer. Based on the results of tests which were carried out with the use of a scanning tunneling microscope (STM) and diffuse ion spectroscopy (ISS), it was found that clusters of copper formed on the surface of $\mathrm{TiO}_{2}$ are three-dimensional (Zhou and Chen 2003). In order to verify obtained results, the DMMP distribution on copper surface and on the surface of titanium oxide (IV) was also examined. Dimethyl methylphosphonate decomposition was carried out using programmable thermocontrol (TPD) from room temperature to the temperature of $576.85^{\circ} \mathrm{C}$ with the increase of $2{ }^{\circ} \mathrm{C} / \mathrm{min}$. The main products of DMMP degradation on $\mathrm{TiO}_{2}$ itself were hydrogen, methyl radical and methane. In this case, there is no complete decomposition of the reagent, because it is present in post-reaction products. Analysis of the obtained products did not show the content of phosphorus compounds, which may indicate that they are deposited on the surface of $\mathrm{TiO}_{2}$ and do not undergo desorption.

In the case of DMMP reactions on the copper surface, the substrate is not completely decomposed, and hydrogen products, methane, methyl radicals, formaldehyde and methanol were observed in gaseous products. The thermal decomposition reaction on copper clusters, regardless of their size, leads to similar products. Under these conditions, formaldehyde and methanol are formed, and probable intermediates are compounds containing a methoxy group that are formed on the surface of copper. These products are preferential on copper coatings covering completely the surface of $\mathrm{TiO}_{2}$, preventing a competitive reaction (running on the surface) of $\mathrm{TiO}_{2}$ ) leading to the formation of only hydrogen, methane and a methyl radical. Studies using photoelectron spectroscopy have shown that DMMP decomposes on copper clusters already at room temperature to carbon atoms, phosphorus and phosphorus oxide particles (POx), which remain on the cluster surface, but the efficiency of this reaction is very small (Lee et al. 1994).

The studies of $\mathrm{TiO}_{2}$ nanoparticles, without additives, using infrared spectroscopy (FTIR) allowed to demonstrate that titanium (IV) oxide nanoparticles show adsorption properties toward DMMP (Panayotov and Morris 2009). Further research allowed to state that $\mathrm{TiO}_{2}$ in the form of nanoparticles catalyzes the oxidation of DMMP in the air already at room temperature. As a result of this reaction, formaldehyde is formed, but the efficiency of this process is not high, and the catalysis reaction time is long, from 15 to even $70 \mathrm{~min}$ (Panayotov and Morris 2009). In the case of thermal degradation of DMMP on a large contact surface- $\mathrm{TiO}_{2}$ nanoparticles-in the temperature range from 22 to $127^{\circ} \mathrm{C}$, there is a nucleophilic attack of oxygen from the air on the adsorbed molecule of this compound, resulting in the formation of $\mathrm{Ti}-\mathrm{OCH}_{3}$ and phosphorus oxides $\left(\mathrm{PO}_{x}\right)$ in the form of surface groups. Above $127^{\circ} \mathrm{C}$, the thermally activated oxygen present in the crystal lattice begins to play a dominant role in the oxidation of $\mathrm{Ti}-\mathrm{OCH}_{3}$ surface groups. The introduction of gold nanoparticles with dimensions smaller than $5 \mathrm{~nm}$ on the surface of $\mathrm{TiO}_{2}$ increases, compared to the unmodified $\mathrm{TiO}_{2}$, catalytic activity toward DMMP (Panayotov and Morris 2008). The reaction of DMMP degradation to $\mathrm{TiO}_{2}$ modified with Au nanoparticles occurs in both anaerobic and aerobic atmosphere and additionally does not require the presence of UV radiation. Gold nanoparticles present on the surface of titanium oxide (IV) are directly involved in the catalytic reaction of DMMP. 
For the thermal decomposition of DMMP, amorphous manganese oxide (AMO) can also be used. AMO for catalysis was prepared as a result of the degradation of $\mathrm{KMnO} 4$, which allowed to obtain powder with a specific surface area $200 \pm 10 \mathrm{~m}^{2} / \mathrm{g}$ (Segal et al. 2001). The use of amorphous manganese oxide in the temperature range of $200-400{ }^{\circ} \mathrm{C}$ as a catalyst for the thermal decomposition of DMMP leads to the formation of carbon dioxide and methyl alcohol (Segal et al. 2001). Figure 2 shows the change in $\mathrm{CO}_{2}$ concentration. The literature data (Segal et al. 1999) shows that in the initial period of degradation at 300 and $400{ }^{\circ} \mathrm{C}$, DMMP disappears completely. Based on carried out experiments, it was found that DMMP undergoes thermal decomposition, catalyzed by amorphous manganese oxide, forming carbon dioxide and methyl alcohol in the gas phase, while on the catalyst surface methyl methylphosphonate (MMP), methylphosphonic acid (MPA) and phosphate ions are deposited. The key parameter affecting the reaction rate of dimethyl methylphosphonate decomposition is the reaction temperature. The DMMP thermocatalysis reaction runs with the highest efficiency at temperature $400{ }^{\circ} \mathrm{C}$.

Dimethyl methylphosphonate can also be used to decompose thermal thin films of cerium (IV) oxide (Chen et al. 2010). As a result of deposition of cerium vapors on the surface of the ruthenium at $427{ }^{\circ} \mathrm{C}$ in an oxygen atmosphere, thin films of $\mathrm{CeO}_{2}$ cerium oxide and partially reduced cerium oxide $\mathrm{Ce}_{2} \mathrm{O}_{3}$ were obtained. The main gaseous products produced during the thermal decomposition of DMMP at $627^{\circ} \mathrm{C}$ of catalyzed cerium oxide are formaldehyde, methanol, water and carbon dioxide, while phosphorus Pox deposits on the surface of the catalyst. Cerium oxide retains catalytic properties for a very long time, which allows for many cycles of reactions, but with each cycle it gradually becomes poisoned, as a result of which its activity decreases. Decrease



Fig. 2 The curves show the change in the amount of $\mathrm{CO}_{2}$ in the gas stream during thermal decomposition of DMMP versus time of the process (reaction conditions: weight of the amorphous manganese oxide $50 \mathrm{mg}$, air flow $30 \mathrm{~mL} / \mathrm{min}$ ) (Segal et al. 2001) in catalytic activity of $\mathrm{CeO}_{2}$ is caused by the passivation of the active catalyst surface due to the deposition of phosphorus oxides on it during the decomposition of DMMP. The second reason for the decrease in the activity of cerium (IV) oxide with each subsequent catalytic cycle is the reduction of $\mathrm{Ce}^{4+}$ to $\mathrm{Ce}^{3+}$. The reoxidation of the cerium, however, does not increase the activity of the catalyst. On the basis of the conducted research, the authors of the work (Guo et al. 1990) proposed a mechanism for the degradation of DMMP on thin films of cerium oxide, which is shown in Fig. 3. At $473{ }^{\circ} \mathrm{C}$, occurs chemisorption of DMMP on the surface of cerium (IV) oxide, with the use of oxygen from the phosphonic group. At this temperature, only a small degradation of the substrate occurs, most likely as a result of the breaking of $\mathrm{P}-\mathrm{OCH}_{3}$ bond. In addition, $\mathrm{O}-\mathrm{P}-\mathrm{O}$ bridges are also very likely to form. After the temperature has risen to $573{ }^{\circ} \mathrm{C}$, all phosphono groups are transformed to $\mathrm{O}-\mathrm{P}-\mathrm{O}$ bridges, and $\mathrm{P}-\mathrm{OCH}_{3}$ bonds are torn apart. Above $400 \mathrm{~K}$, desorption of DMMP particles and traces of methanol and formaldehyde takes place. Under these conditions, the exchange of oxygen from cerium (IV) oxide with DMMP probably also takes place, which is used to form $\mathrm{O}-\mathrm{P}-\mathrm{O}$ bridges. At a temperature of $773{ }^{\circ} \mathrm{C}, \mathrm{O}-\mathrm{P}-\mathrm{O}$ bridge joints are still formed, but most likely they arise as a result of the combination of methylphosphonate with the catalyst surface, since most of the $\mathrm{P}-\mathrm{OCH}_{3}$ bonds break. At $848{ }^{\circ} \mathrm{C}$ takes place desorption of formaldehyde and methanol. However, after exceeding the temperature of $973{ }^{\circ} \mathrm{C}$, an intermediate product is formed, which is methylphosphonate, as evidenced by the

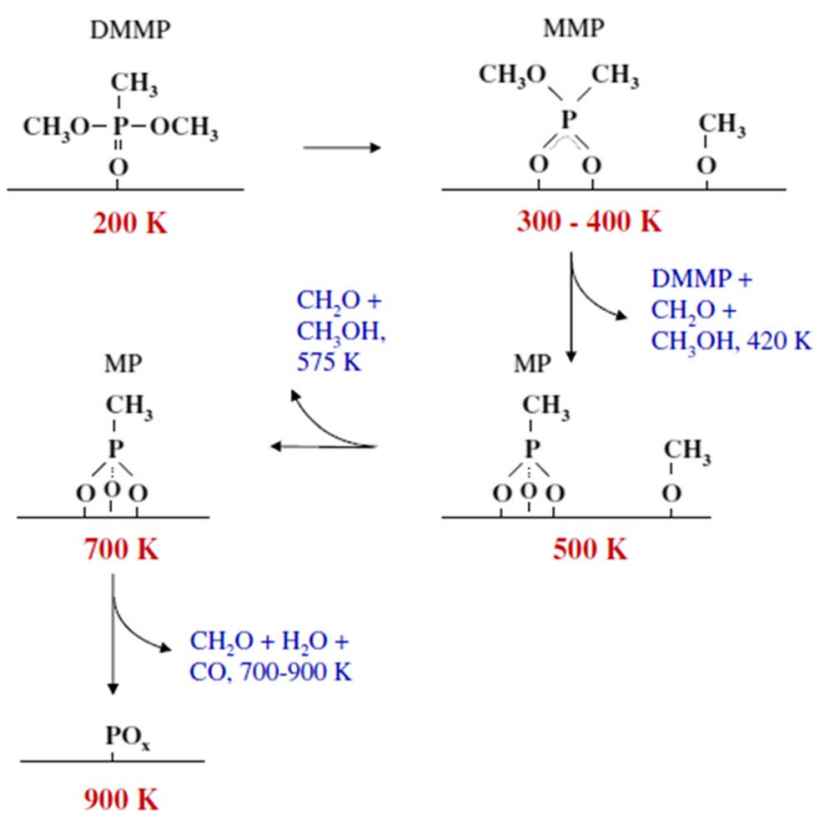

Fig. 3 DMMP disposal diagram on a thin film made of cerium oxide (IV). POx intermediates are formed which decrease the activity of the catalyst for the decomposition of DMMP (Guo et al. 1990) 
lack of $\mathrm{O}-\mathrm{P}-\mathrm{O}$ bridge connections and too low temperature, in which $\mathrm{P}-\mathrm{CH}_{3}$ bond is not broken yet. At $1073{ }^{\circ} \mathrm{C}$, methane is formed due to the disruption of the $\mathrm{CH} 3 \mathrm{P}$ bond, and additionally under these conditions, formaldehyde and water are formed as products. At $1173{ }^{\circ} \mathrm{C}$, in addition to gaseous products, solid products are also deposited on the surface of the catalyst. These are mainly oxides of phosphorus POx, while no carbon is observed (Guo et al. 1990).

In the case of the DMMP degradation study under high vacuum conditions on nickel (111) and palladium (111) crystals, it was found that the main products of this reaction were carbon monoxide, water, hydrogen, phosphorus and small amounts of carbon (Cao et al. 2000). Thermal decomposition of DMMP, in the absence of oxygen, occurred both on the surface of palladium at a temperature below $573{ }^{\circ} \mathrm{C}$ and nickel at a temperature below $613^{\circ} \mathrm{C}$. This reaction produces hydrogen and carbon monoxide, while on the catalyst surface, phosphorus is deposited. Phosphorus from the catalyst surface can be removed by oxidation at $1348{ }^{\circ} \mathrm{C}$, a process that is not effective for nickel surfaces. A comparison of similar experiments carried out on the surface of molybdenum shows that transition metals may be suitable for the thermocatalytic oxidation of organophosphorus compounds. This is due to the fact that the removal of phosphorus, arising during the DMMP decomposition reaction, from the surface of molybdenum, takes place at a lower temperature (Graven et al. 1966).

Ratliff et al. (2009) describe the results of the research on the thermocatalytic distribution of sarin simulantDMMP - concentration of which was $1300 \mathrm{ppm}$. The experiment was conducted in the temperature range of $946-996{ }^{\circ} \mathrm{C}$, and the carrier gas was air of very high purity. Systems (catalyst/carrier) were tested: $\mathrm{Al}_{2} \mathrm{O}_{3}, 10 \% \mathrm{Fe} / \mathrm{Al}_{2} \mathrm{O}_{3}$, $10 \% \mathrm{Ni} / \mathrm{Al}_{2} \mathrm{O}_{3}, 10 \% \mathrm{Cu} / \mathrm{Al}_{2} \mathrm{O}_{3}, 1 \% \mathrm{Pt} / \mathrm{A}_{12} \mathrm{O}_{3}, 10 \% \mathrm{~V} / \mathrm{Al}_{2} \mathrm{O}_{3}$. The analyzed materials showed some catalytic activity in the decomposition reaction of the sarin simulant, which decreased with time (Fig. 4).

On the basis of the conducted research, it was found (Graven et al. 1966) that the most durable catalyst is $10 \% \mathrm{~V} / \mathrm{Al}_{2} \mathrm{O}_{3}$, for which the highest conversion of DMMP after $20 \mathrm{~h}$ of the experiment was obtained. It also has much longer durability than other materials (e.g., $1 \% \mathrm{Pt} / \mathrm{Al}_{2} \mathrm{O}_{3}$ ), described in publications (Ratliff et al. 2009; Cao et al. 2001). $\mathrm{P}_{2} \mathrm{O}_{5}$ resulting from the degradation of DMMP in the presence of $10 \% \mathrm{~V} / \mathrm{Al}_{2} \mathrm{O}_{3}$ reacts with $\mathrm{Al}_{2} \mathrm{O}_{3}$ forming $\mathrm{AlPO}_{4}$, which reduces the active surface of the catalyst, which probably causes its gradual deactivation. However, when using vanadium (on $\mathrm{SiO}_{2}$ carrier), which does not react with the $\mathrm{P}_{2} \mathrm{O}_{5}$, the active surface of the catalyst was not reduced. The effect of temperature on DMMP conversion was also examined. It was found that at $896^{\circ} \mathrm{C}$, the conversion rate of the analyzed sarin simulant decreases slightly after about $8 \mathrm{~h}$ and after $30 \mathrm{~h}$ reaches the level

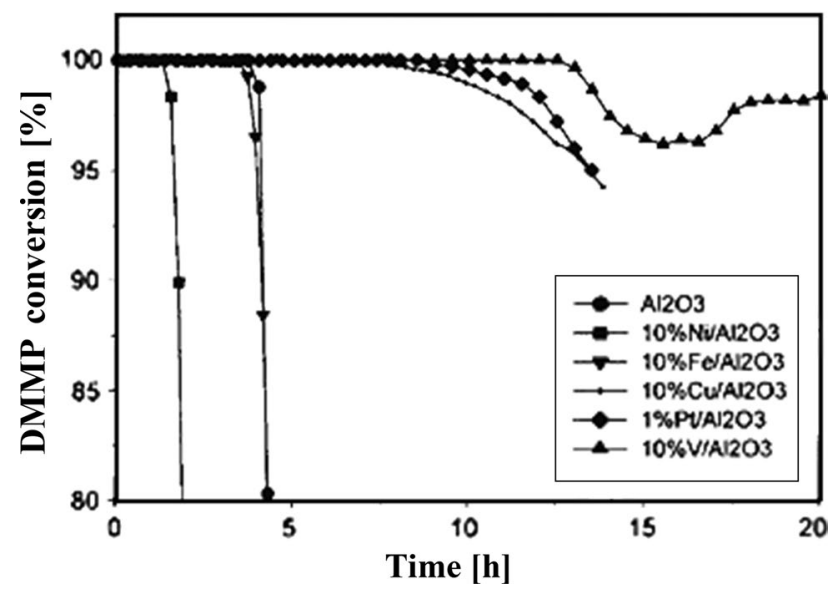

Fig. 4 DMMP degree of conversion as a function of time, depending on the used catalyst (Graven et al. 1966)

of $91 \%$. However, at $673 \mathrm{~K}$, the conversion efficiency is set at around $99 \%$. The full thermocatalytic degradation of DMMP was obtained only at $996{ }^{\circ} \mathrm{C}$ and the process stability exceeded $100 \mathrm{~h}$.

Jóźwik et al. (2010) describe the studies of thermocatalytic efficiency using activated carbon with a specific surface area of $897.5 \mathrm{~m}^{2} / \mathrm{g}$. At $846{ }^{\circ} \mathrm{C}$, the efficiency of DMMP decomposition was continuously reduced from the very beginning of the process. At $896^{\circ} \mathrm{C}$, the conversion was maintained for approx. $10 \mathrm{~h}$, and at $946^{\circ} \mathrm{C}$ for approx. $26 \mathrm{~h}$. At $996^{\circ} \mathrm{C}$, the total degradation of DMMP was observed at $100 \mathrm{~h}$, which is evidence of high process stability.

Thus, it has been shown (Popiel et al. 2014; Graven et al. 1966) that DMMP decomposition results in: $\mathrm{CO}_{2}$, methanol and $\mathrm{P}_{2} \mathrm{O}_{5}$. For comparison, it is worth noting that during the analysis of DMMP by mass spectroscopy during electron ionization the decomposition products were methyl methylphosphonate and methylphosphonic acid. In the classic process, decomposition takes place in two stages. In the first stage, $\mathrm{CO}_{2}$, methanol and $\mathrm{P}_{2} \mathrm{O}_{5}$ are formed. In the second stage, $\mathrm{P}_{2} \mathrm{O}_{5}$ is formed, and it deposits on the walls of the reactor and becomes a catalyst for further degradation of DMMP.

Promising properties had also the catalyst that was made from an alloy based on intermetallic $\mathrm{Ni}_{3} \mathrm{Al}$ phase. In many works (Jóźwik et al. 2011, 2014; Jang et al. 2011; Hirano et al. 2011; Chun et al. 2006; Arkatova 2010; Zuo et al. 2007), catalytic activity of bands made of this material in the decomposition reaction has been demonstrated for methanol, hexane, sarin, sulfur mustard and their simulant. The tests presented lately (Jóźwik et al. 2011) were performed in a standard flow system with a fixed catalyst bed. $\mathrm{Ni}_{3} \mathrm{Al}$ band cut into square flakes with a side of $1 \mathrm{~mm}$ was placed in the reactor and filled with a quartz pestle with a grain size of $0.5-1 \mathrm{~mm} .500 \mathrm{ppm}$ organic compound was introduced into the reactor. The catalyst tested showed high activity in 
the DMMP decomposition reaction, which increased as the process temperature increased reaching a conversion close to $100 \%$ at a temperature of approximately $450{ }^{\circ} \mathrm{C}$ (Fig. 5). The analysis of DMMP conversion products showed the formation of compounds such as MMP, formaldehyde and methanol in addition to water and carbon oxides.

\section{Photocatalysis}

A large number of studies have focused on the development of effective catalysts and reactive materials for the destruction of CWAs, but the most promising systems require photochemistry. One of the most widely studied systems for the degradation of CWAs is nanoparticulate $\mathrm{TiO}_{2}$ (Moss et al. 2005; Trubitsyn and Vorontsov 2005).

The fumes of sarin and sulfur mustard can be successfully deactivated by means of ultraviolet (UV) radiation generated from germicidal lamps by means of both photolysis and photocatalysis. Sarin and sulfur mustard can polymerize after irradiation with UV light. A photocatalytic reaction, e.g., on the surface of $\mathrm{TiO}_{2}$, leads to the formation of simple inorganic compounds. Research has shown that photolysis or photocatalysis can be used to clean air in large rooms contaminated with sarin.

Kozlova and Vorontsov (2006) describe the photocatalytic oxidation of DMMP, in an aqueous suspension of $\mathrm{TiO}_{2}$, using oxygen from the air. A Degussa P25 catalyst was used with a surface modified with platinum and palladium. The catalysts obtained in this way showed almost three times more activity than the best standard Degussa P25-type photocatalysts. Kinetic curves of DMMP oxidation to $\mathrm{TiO}_{2}$ and $\mathrm{Pt} / \mathrm{TiO}_{2}$ can be successfully approximated using the Langmuir-Hinshelwood model, taking into account the effect of oxygen adsorption and DMMP. An increase in catalytic activity of $\mathrm{Pt} / \mathrm{TiO}_{2}$ may be associated with higher adsorption of oxygen or with another rate of reaction. Studies have shown that

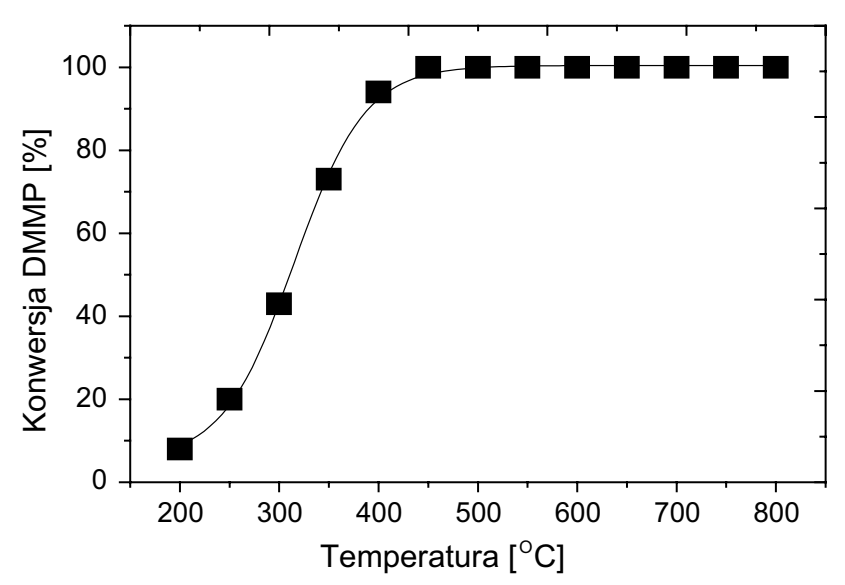

Fig. 5 DMMP conversion efficiency on the surface of thin strips of $\mathrm{Ni}_{3} \mathrm{Al}$ as a function of the temperature (Jóźwik et al. 2011) photocatalysts with a porous structure show greater catalytic activity compared to suspension photocatalysts.

It is also possible to use solid aerosols with a high content of $\mathrm{TiO}_{2}$, generated by ultrasonic methods, to purify air contaminated with vapors of chemical warfare agents. DMMP adsorption on $\mathrm{TiO}_{2}$ leads to almost immediate (less than $10 \mathrm{~s}$ ) and irreversible hydrolysis of DMMP, resulting in the formation of methanol and adsorbed methyl methylphosphonic acid in the gaseous form. The very short time needed to clean the air contaminated with DMMP (20-40 s) is due to the use of solid aerosols of $\mathrm{TiO}_{2}$, which allow to shorten the distance between their catalytical surface and contaminat, in addition, the contaminant-catalyst contact surface is relatively large. The increase in relative air humidity from 4 to $37 \%$ at $296 \mathrm{~K}$ causes a significant slowdown in the DMMP adsorption process, but accelerates the process of photocatalytic oxidation. Complete purification of air from organic compounds is possible using photocatalytic oxidation in a period not exceeding $10 \mathrm{~min}$. The time needed to purify the air with a solid aerosol containing $\mathrm{TiO}_{2}$ is directly related to the time needed to generate this aerosol (Neat et al. 2009).

Another work (Neatu et al. 2008) that contains a comparison of the influence of sunlight (impact on physical adsorption) with ultraviolet radiation (impact on catalytic processes) on the efficiency of sulfur mustard decomposition on $\mathrm{TiO}_{2} / \mathrm{SiO}_{2}$ surface was conducted. The obtained test results were compared with the efficiency of decomposition of this compound on the catalyst with the addition of manganese or vanadium (Fig. 6). In the case of enriched catalysts ( $\mathrm{Mn}, \mathrm{V}$ and $\mathrm{Fe}$ ), the highest level of sulfur mustard decomposition was obtained, i.e., above $75 \%$.

On the basis of the results presented in this paper (Neatu et al. 2008), it can be stated that the sulfur mustard has a lower efficiency (conversion of 10-15\%) in the case of daylight. The phenomenon has been explained by the authors (Neatu et al. 2008) that the molar coefficient of visible radiation absorption has a lower value than for UV radiation, which in turn affects the reaction speed. Quite good adsorptive properties of used, non-doped material $\left(\mathrm{TiO}_{2} /\right.$ $\mathrm{SiO}_{2}$ ) were enough to obtain a distribution of sulfur mustard of approximately $40 \%$ using UV radiation. In addition, it should be noted that doped materials such as Mn can catalyze the decomposition of sulfur mustard under the influence of UV radiation even at the level of $90 \%$.

Many authors (Moss et al. 2005; Trubitsyn and Vorontsov 2005; Kozlova and Vorontsov 2006; Neat et al. 2009; Neatu et al. 2008) have also showed that vapors of poisonous sarin can be effectively deactivated by means of UV radiation. The results are shown in Fig. 7. UV radiation has an effect on the breakdown of sarin. In non-irradiated gas, the concentration is reduced to $80 \%$ in $2 \mathrm{~h}$. On the other hand, after irradiation with UV light, the concentration decreases to approx. $30 \%$ within $1 \mathrm{~h}$, and the total decomposition takes place 


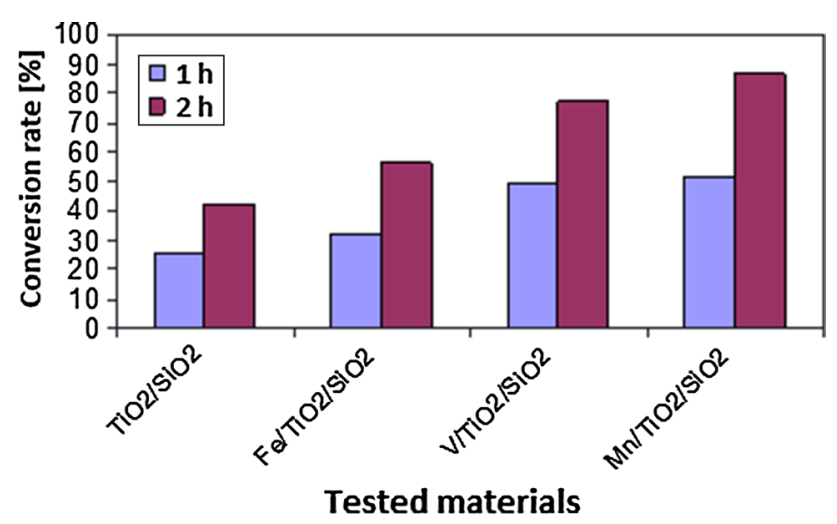

Fig. 6 The degree of photocatalytic decomposition of sulfur mustard with the selected catalyst (the reaction conditions are: air flow of 50 $\mathrm{cm}^{3} / \mathrm{min}$, the catalyst quantity $20 \mathrm{mg}$, time of irradiation with UV-1 and $2 \mathrm{~h}$, atmospheric pressure) (Neatu et al. 2008)

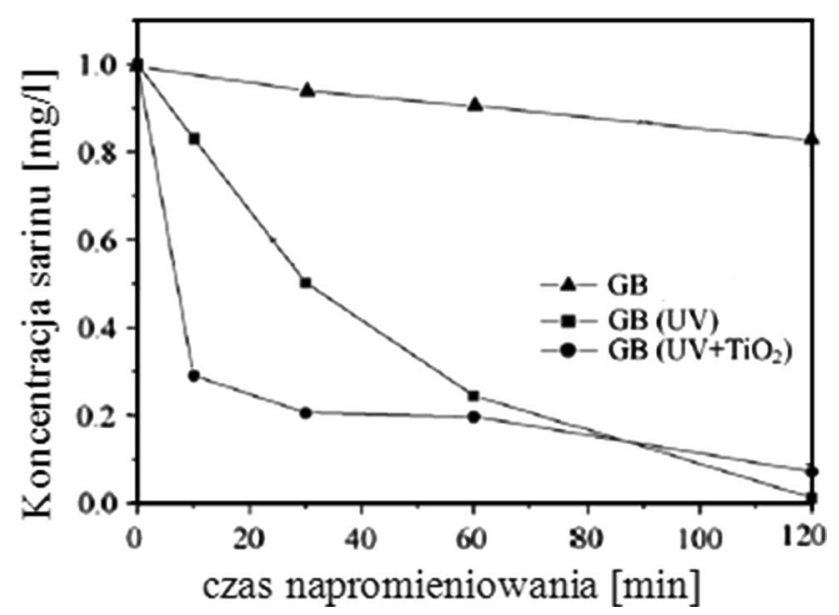

Fig. 7 The concentration of sarin as a function of irradiation time for the reaction of the photolysis (GB) and photocatalysis (GB (UV) and German $\left(\mathrm{UV}+\mathrm{TiO}_{2}\right)$ ). Sarin initial concentration of $1.7 \mathrm{mg} / \mathrm{L}$, radiation intensity $0.6 \mathrm{~mW} / \mathrm{cm}^{2}$, humidity $30-50 \%$, weight of $\mathrm{TiO}_{2}$ of $0.3 \mathrm{~g}$ (Neat et al. 2009)

within the next hour. In case when $\mathrm{TiO}_{2}$ was added to the system, disintegration to the level of $30 \%$ occurred already after $10 \mathrm{~min}$, which ultimately confirms the efficiency of this oxide as a catalyst for CWA decomposition.

During the degradation, studies of chemical warfare agents have mainly used commercially available single metal oxides, most commonly $\mathrm{TiO}_{2}$ (Moss et al. 2005; Kiselev et al. 2006; Rusu and Yates 2000). However, in order to increase decontamination efficiency, doped $\mathrm{TiO}_{2}$ with metal or non-metal ions (Ramacharyulu et al. 2014; Mattsson et al. 2009), or various nanocomposites (Giannakoudakis et al. 2016), has been recently adopted and applied. In particular, combinations of metal oxides or hydroxides with low-dimensional materials appear very promising. Easily accessible carbon materials such as nanotubes (Yang et al. 2013), graphene (Yang et al. 2013), or graphene oxide (GO)
(Shah et al. 2012) are among the most studied systems. However, synthesis of these fascinating materials on large scale remains challenging. Stengl et al. have previously reported two undemanding methods suitable for large-scale synthesis of $\mathrm{TiO}_{2}$-based nanocomposites (Stengl et al. 2011, 2013).

Nowadays, large efforts have been continuously attempting breakthroughs from new materials and new technologies. Reactive sorbents have gradually come to the fore, and in particular, $\mathrm{TiO}_{2}$ nanomaterials have been widely explored as possible photocatalysts for CWAs decontamination. To date, much research has been conducted on the photocatalytic degradation efficiency and mechanism of HD, GD, VX, 2-CEES and DMMP on metal ions doped $\mathrm{TiO}_{2}$ (Stengl et al. 2011, 2012; Osterlund et al. 2009; Mattsson et al. 2009).

The sub-zero temperature decontamination performance of the following chemical warfare agents: sulfur mustard (HD), soman (GD) and S-2-(diisopropylamino)ethyl O-ethyl methylphosphonothiolate (VX) as well as their simulants (2-chloroethyl ethyl sulfide (2-CEES)) and dimethyl methylphosphonate (DMMP)) on a novel nanoparticulate $\mathrm{Zn}^{2+}$ and $\mathrm{Ge}^{4+}$ co-doped titanium dioxide $\left(\mathrm{Zn}-\mathrm{Ge}-\mathrm{TiO}_{2}\right)$ material (Shen et al. 2018) has been studied. To discover further progress toward the practice use of the powdered catalyst and improve its low-temperature decontamination, a novel suspension decontaminant was prepared successively by suspending $\mathrm{Zn}-\mathrm{Ge}-\mathrm{TiO}_{2}$ in partially fluorinated ethyl-propyl ether (HFE-458, $\mathrm{C}_{5} \mathrm{H}_{4} \mathrm{~F}_{8} \mathrm{O}$ ). It has been proved that $\mathrm{Zn}$ $(5.28 \mathrm{wt} \%)-\mathrm{Ge}(1.48 \mathrm{wt} \%)-\mathrm{TiO}_{2}$ exhibited the best photocatalytic performance. In comparison with undoped $\mathrm{TiO}_{2}$, the new material has unchanged crystal structure (anatase) and decreased average pore diameter. Under simulated sunlight irradiation at $-30^{\circ} \mathrm{C}$, after a reaction time of $120 \mathrm{~min}$, the degradation efficiency of HD, GD and VX on the suspension composed as it was described above was all over 99.95\%. This indicated that the suspension has a promising possibility of application in CWAs decontamination under the temperature below $0{ }^{\circ} \mathrm{C}$.

\section{Enzymes used to neutralize chemical warfare agents}

Mazur (1946) described for the first time report on enzymatic methods for the detoxification of organophosphorus nerve agents. He found that human and rabbit tissues, blood and plasma contain an enzyme that accelerates the hydrolysis of dialkyl fluorophosphates. Mazur managed to partially characterize the enzyme obtained from the rabbit kidney and stated that dialkyl fluorophosphates either irreversibly block cholinesterase or are detoxified by enzymatic catalyzed hydrolysis, mainly in the liver.

Enzyme phosphotriesterase (PTE, EC 3.1.8.1) has catalytic activity against many organophosphorus compounds 
(Zhang et al. 2009; Bigley et al. 2013; Cherny et al. 2013), and the highest catalytic capacity is observed for the pesticide paraoxon (Aubert et al. 2004). The reaction rate constant for the decomposition of paraoxon catalyzed by PTE is $\mathrm{k}_{\mathrm{cat}}=2280 \mathrm{~s}^{-1}$. The value determining the specificity of the enzyme relative to the selected substrate is the ratio of the reaction rate of constant to Michaelis constant for paraoxon (substrate) and PTE (enzyme) and is $k_{\text {cat }} / K_{\mathrm{m}}=6.2107 \mathrm{M}^{-1} \mathrm{~s}^{-1}$ (Omburo et al. 1992); for example, this value for selected CWAs is as follows: sarin $-8 * 10^{4}$, soman $-10^{4}$ and VX $-7 * 10^{2}$ (Di Sioudi et al. 1999). The phosphotriesterase exhibits catalytic activity against a wide range of compounds, both containing phosphoryl and thiophosphoryl groups (Hong and Raushel 1996). PTE is one of the enzymes that can catalyze the breakdown of P-S bond (Hoskin et al. 1995; Rastogi et al. 1997) which is present in CWAs such as VX. Phosphotriesterase catalyzes the decomposition of compounds whose leaving group is a single ion, e.g., fluoride ion in sarin or soman, as well as large leaving group in VX. The rate of catalyzed reaction in this case depends on the $\mathrm{pK}_{\mathrm{a}}$ of the leaving group (Hong and Raushel 1996).

Another enzyme which has the ability to catalyze the hydrolysis of organophosphorus nerve agents is paraoxonase 1 (PON1, EC 3.1.8.1) (Blum et al. 2006); this enzyme is present in the human body. The presence of this enzyme is very important in the context of the human organism defense against these highly toxic compounds (Yeung et al. 2007). PON efficiently catalyzed hydrolyses of G-type CWAs and even shows a small catalytic activity toward decomposition of VX (Broomfield et al. 2000).

Organophosphorus acid anhydrase (OPAA, EC 3.1.8.2) does not catalyze the hydrolysis of VX, but very effectively accelerates the breakdown of $\mathrm{P}-\mathrm{F}$ and $\mathrm{P}-\mathrm{CN}$ bonds in G-type chemical warfare agents such as tabun, soman or sarin (Cheng et al. 1996; Hill et al. 2001). Enzymatic activity $\left(k_{\text {cat }}\right)$ of OPPA against nerve agents is as follows: DFP-1650 s ${ }^{-1}$, tabun-85 s $\mathrm{s}^{-1}$, sarin-611 s $\mathrm{s}^{-1}$, soman$3145 \mathrm{~s}^{-1}$, cyclosarin-1650 s ${ }^{-1}$ (Cheng et al. 1999). OPAA exhibit stereoselectivity during catalyze the decomposition of CWAs, showing a preference for less toxic stereoisomer (Hill et al. 2001). The enzyme is more active against the $\mathrm{R}_{\mathrm{P}}$-enantiomers of sarin; the $k_{\mathrm{cat}} / K_{\mathrm{m}}$ ratio for the $\mathrm{R}_{\mathrm{P}}$-enantiomer is $250 \mathrm{M}^{-1} \mathrm{~s}^{-1}$ and for the $\mathrm{S}_{\mathrm{P}}$-enantiomer $100 \mathrm{M}^{-1} \mathrm{~s}^{-1}$. For soman stereoisomers, we can observe the following relationship: $R_{\mathrm{P}} S_{\mathrm{C}}>\mathrm{R}_{\mathrm{P}} \mathrm{R}_{\mathrm{C}}>\mathrm{S}_{\mathrm{P}} \mathrm{R}_{\mathrm{C}}>\mathrm{S}_{\mathrm{P}} \mathrm{S}_{\mathrm{C}}$. The $k_{\mathrm{cat}} / K_{\mathrm{m}}$ ratios are, respectively, $36,300 \mathrm{M}^{-1} \mathrm{~s}^{-1}$, $1250 \mathrm{M}^{-1} \mathrm{~s}^{-1}, 80 \mathrm{M}^{-1} \mathrm{~s}^{-1}$ and $5 \mathrm{M}^{-1} \mathrm{~s}^{-1}$ (Hill et al. 2001).

Decomposition and detoxification of organophosphorus compounds can also occur as a result of hydrolysis reactions catalyzed by enzyme DFPase (EC 3.1.8.2) (Allahyari and Latifi 2016). DFPase effectively catalyzes the hydrolysis reaction of DFP, sarin, soman, tabun and cyclosarin but does not catalyze the hydrolysis of VX and paraoxon (Blum et al.
2006). A certain degree of stereoselectivity was noticed, but complete detoxification can still be achieved using wild type of enzyme. The catalytic efficiency of enzymatic hydrolysis expressed by $k_{\mathrm{cat}} / K_{\mathrm{M}}$ ratio for individual soman isomers is in the range of one order (Yeung et al. 2007).

The hydrolytic decomposition of sulfur mustard is not a trivial problem due to its poor solubility in water. The enzyme that can accelerate the hydrolysis of sulfur mustard is Haloalkane Dehalogenase (EC 3.8.1.5) (Jasenska et al. 2002). This enzyme has the ability to catalyze the hydrolysis of a carbon-halogen bond (Jasenska et al. 2005). Decontamination of sulfur mustard catalyzed by haloalkane dehalogenase leads to the formation of the corresponding products including thiodiglycol (non-toxic), a proton and a halide (Khabiri et al. 2013; Zhao et al. 2018). However, the low resistance to the elevated temperatures limited the application of haloalkane dehalogenases (Guo et al. 2015). Alternative for this enzyme is new thermotolerant dehalogenase FM2382 from Fulvimarina manganoxydans sp. nov. 8047 (Zhao et al. 2018). The specific activity of FM2382 possessed high thermal stability $\left(45^{\circ} \mathrm{C}\right)$ in slight alkali environment $(\mathrm{pH} 7.5)$ and retained approximately $50 \%$ activity after incubation at $70{ }^{\circ} \mathrm{C}$ for $40 \mathrm{~min}$. The catalytic activity of FM2382 was activated by $\mathrm{Co}^{2+}$ and $\mathrm{Mg}^{2+}$ and inhibited by $\mathrm{Zn}^{2+}, \mathrm{Cu}^{2+}$ and $\mathrm{Fe}^{3+}$. Main products of enzymatic hydrolysis are 2-ethyl ethyl mercaptan and thiodiglycol. Other alternative for detoxification of sulfur mustard is used of nucleophilic scavengers, such as thiopurines (Liu et al. 2010).

Another enzyme that can be catalyzed decontamination of sulfur mustard is chloroperoxidase (CPO, EC 1.11.1.10) (Popiel and Nawała 2013). Chloroperoxidase is a universal enzyme that catalyzes the oxidation of a wide range of organic compounds and also catalyzes the chlorination of nucleophilic substrates. CPO catalyzes the oxidation of sulfur mustard and VX compound causing their neutralization (Popiel et al. 2010). In aqueous solutions containing $\mathrm{CPO}$, hydrogen peroxide or urea complex with hydrogen peroxide and sodium chloride, there we can observe a rapid degradation of VX or sulfur mustard. Decontamination of pigs ears spiked with the VX by mixture containing CPO, urea complex with hydrogen peroxide and $\mathrm{NaCl}$, allows to decompose up to $98 \%$ of the nerve agent. At $25^{\circ} \mathrm{C}$ and at $\mathrm{pH}$ 2.75 , the half-life time of VX was $8 \mathrm{~s}$. In the case of sulfur mustard, an aqueous solution with a $\mathrm{pH}$ of 2.75 containing $\mathrm{CPO}$, urea complex with hydrogen peroxide $(0.05 \mathrm{M})$ and $\mathrm{NaCl}(0.5 \mathrm{M})$ causes the degradation of $99 \%$ of the substrate in 10 min. Detoxification of sulfur mustard by CPO leads to the formation of sulfoxide and sulfone, which then spontaneously decomposes to divinyl sulfone (Rastogi et al. 1997).

Another group CWAs, which have a wide range of toxic effects (from choking to blistering), are arsenic compounds. However, so far there are not any reports on the activity of enzymes against CWAs containing As in their structure. But 
we can find works describing the activity of enzymes against organic arsenic compounds (Rezanka and Sigler 2008; Hampton et al. 2018). For example, bacteria Halomonas sp. is capable of using arsenic to sustain growth (Wolfe-Simon et al. 2011). This bacterial is able to detoxify arsenate compounds through two cooccurrence pathways, and these pathways directly detoxify arsenate instead of performing the typical conversion of As(V) to As(III) and extrusion of As(III) (Wu et al. 2018). Another bacterium that can detoxify arsenic compounds is Ralstonia eutropha Q2-8 (Wang et al. 2018). This bacterium can alleviate the toxicity of As to wheat plants and reduce aboveground tissue As uptake by increasing the expression of the root energy-, defense-, cell wall organization- and cell wall biosynthesis-related proteins. It occurs by increasing biomass and in consequence reducing arsenic uptake in wheat plants. The arsH gene is found in many arsenic resistance operons, implying a role in arsenic detoxification (Canovas et al. 2003). ArsH has previously been characterized as a reductase with various substrates, for example reduction of azo dyes and $\mathrm{O}_{2}-\mathrm{H}_{2} \mathrm{O}_{2}$ (Ye et al. 2007) or Fe(III)-Fe(II) (Xue et al. 2014). ArsH from Sinorhizobium meliloti oxidized MAs(III), PhAs(III) and Rox(III) when the reductant nicotinamide adenine dinucleotide (NADPH) was supplied (Chen et al. 2015). These data are very promising in the context of the organic arsenic CWAs disposal, but studies directly on these compounds are required.

Organophosphorus hydrolases have found application in the construction of biosensors for detect of organophosphorus compounds. The use of OPH enzyme instead of ELISA tests allowed to reduce the time needed to detect the presence of toxic compounds, reduced costs and allows for onsite analysis (Singh and Walker 2006). The American company Reactive surfaces ${ }^{\circledR}$ (Austin, Texas) produces mixture called OPDtox ${ }^{\mathrm{TM}}$ containing organophosphorus hydrolases (McDaniel et al. 2006). This formulation is added to paints or other protective coatings against organophosphorus compounds. More and more attention is paid to the possibility of using enzymes for human against CWAs. Enzymes can also be used as an antidote in the case of human exposure to CWAs (Amitai et al. 2003; Cheng et al. 1999; Grimsley et al. 2001). Research centers conducted studies to integrate enzymes with fabric structure, from which protective clothes against the CWAs will be built (Singh et al. 2004).

\section{Conclusion}

Currently, widely used decontaminants are alkaline and/or oxidizing substances that adversely affect the decontaminated objects and the natural environment. Some of them are combustible, and their transportation requires specialized means of transport. Therefore, it becomes a very important task to develop decontaminants that will be free from these disadvantages. New decontaminants should quickly and efficiently destroy chemical warfare agents, and the substances resulting from these processes must show much lower toxicity than the original compounds or even have no toxic properties. In addition, care should also be taken to ensure that decontamination products are not harmful to people and the environment, as well as military and civilian equipment.

In connection with all cited aspects, the catalytic processes carry a lot of potential in the field of decontamination. The use of catalytic methods in the processes of decontamination of chemical warfare agents is supported by the following features: no toxicity, no corrosion, biodegradability, high efficiency and the possibility of combining these methods with other methods.

The most popular modern methods of decontamination of chemical warfare agents include: thermocatalysis, photocatalysis and enzymatic catalysis. From the point of view of emerging products and the reaction environment, enzymatic methods seem to be the best. The reactions catalyzed by enzymes occur in the aquatic environment at a $\mathrm{pH}$ close to neutral for humans. However, the big deficiency of enzymes is that they are relatively unstable and cannot be stored for a long time, which limits their use as decontaminants.

Of all the catalytic methods used to neutralize CWA, thermal technologies have good potential because they ensure the complete decomposition of hazardous substances into products of low toxicity or to non-toxic products. In addition, they do not require complicated equipment and additional reagents. The only requirement for this type of processes is to provide large amounts of heat. In case of photocatalytic methods, the decomposition of CWAs can be achieved easier than for thermal decomposition, but this technique requires more advanced equipment. Enzymatic methods have the greatest potential, and full detoxification of chemical warfare agents can be reached very fast. In the case of this technique, the decomposition products are always non-toxic. In addition, the use of enzymes fulfills the principles of green chemistry.

Acknowledgements The work was carried out as part of the research project PBS3/A5/50/2015 and the international project \# R013 DAIMON co-financed under the Interreg Baltic Sea Program 2014-2020.

Open Access This article is distributed under the terms of the Creative Commons Attribution 4.0 International License (http://creativeco mmons.org/licenses/by/4.0/), which permits unrestricted use, distribution, and reproduction in any medium, provided you give appropriate credit to the original author(s) and the source, provide a link to the Creative Commons license, and indicate if changes were made.

\section{References}

Allahyari H, Latifi AM (2016) Diisopropyl-fluorophosphatase as a catalytic bioscavenger. J Appl Biotechnol Rep 3:477-482 
Amitai G, Adani R, Hershkovitz M, Bel P, Rabinovitz I, Meshulam H (2003) Degradation of VX and sulfur mustard by enzymatic haloperoxidation. J Appl Toxicol 23:225-233

Arkatova LA (2010) The deposition of coke during carbon dioxide reforming of methane over intermetallides. Catal Today 157:170-176

Aubert SD, Li Y, Raushel FM (2004) Mechanism for the hydrolysis of organophosphates by the bacterial phosphotriesterase. Biochemistry 43:5707-5715

Bartelt-Hunt SL, Barlaz MA, Knappe DRU, Kjeldsen P (2006) Fate of chemical warfare agents and toxic industrial chemicals in landfills. Environ Sci Technol 40:4219-4225

Battin-Leclerc F, Baronnet F, Paternotte G, Leclerc JP, Gourhan R (2000a) Thermal decomposition of chloropicrin, diphosgene and phosgene between 100 and $530{ }^{\circ} \mathrm{C}$. J Anal Appl Pyrol 53:95-105

Battin-Leclerc F, Baronnet F, Paternotte G, Leclerc JP, Gourhan R (2000b) Thermal decomposition of bis (2-chloroethyl) sulphide and bis (2-chloroethyl) ether between 300 and $500{ }^{\circ} \mathrm{C}$. J Anal Appl Pyrol 55:203-216

Bigley AN, Xu C, Henderson TJ, Harvey SP, Raushel FM (2013) Enzymatic neutralization of the chemical warfare agent VX: evolution of phosphotriesterase for phosphorothiolate hydrolysis. J Am Chem Soc 135(28):10426-10432

Bismuth C, Borron SW, Baud FJ, Barriot P (2004) Chemical weapons: documented use and compounds on the horizon. Toxicol Lett 149:11-18

Blum MM, Lohr F, Richardt A, Ruterjans H, Chen JCH (2006) Binding of a designed substrate analogue to diisopropyl fluorophosphatase: implications for the phosphotriesterase mechanism. J Am Chem Soc 128:12750-12757

Broomfield CA, Morris BC, Anderson R, Josse D, Masson P (2000) Conference proceedings CBMTS III, May 2000, Spiez, Switzerland. www.jmcdcbr.org

Canovas D, Cases I, de Lorenzo V (2003) Heavy metal tolerance and metal homeostasis in Pseudomonas putida as revealed by complete genome analysis. Environ Microbiol 5:1242-1256

Cao LX, Segal SR, Suib SL, Tang X, Satyapal S (2000) Thermocatalytic oxidation of dimethyl methylphosphonate on supported metal oxides. J Catal 194:61-70

Cao L, Suib SL, Tangy X, Satyapal S (2001) Thermocatalytic decomposition of dimethyl methylphosphonate on activated carbon. $\mathbf{J}$ Catal 197:236-243

Chen DA, Ratliff JS, Hua X, Gordon WO, Senanayake SD, Mullins DR (2010) Dimethyl methylphosphonate decomposition on fully oxidized and partially reduced ceria thin films. Surf Sci 604:574-586

Chen J, Bhattacharjee H, Rosen BP (2015) ArsH is an organoarsenical oxidase that confers resistance to trivalent forms of the herbicide monosodium methylarsenate and the poultry growth promoter roxarsone. Mol Microbiol 96(5):1042-1052

Cheng T-C, Harvey SP, Chen GL (1996) Cloning and expression of a gene encoding a bacterial enzyme for decontamination of organophosphorus nerve agents and nucleotide sequence of the enzyme. Appl Environ Microbiol 62:1636-1641

Cheng T-C, DeFrank JJ, Rastogi VK (1999) Alteromonas prolidase for organophosphorus G-agent decontamination. Chem Biol 119-120:455-462

Cherny I, Greisen P Jr, Ashani Y, Khare SD, Oberdorfer G, Leader H, Baker D, Tawfik DS (2013) Engineering V-type nerve agents detoxifying enzymes using computationally focused libraries. ACS Chem Biol 8(11):2396-2403

Chun DH, Xu Y, Demura M, Kishida K, Wee DM, Hirano T (2006) Catalytic properties of $\mathrm{Ni}_{3} \mathrm{Al}$ foils for methanol decomposition. Catal Lett 106:71-75

Committee on Review and Evaluation of the Army Chemical Stockpile Disposal Program (1996) Review of Systematization of the
Tooele Chemical Agent Disposal Facility, The National Academies Press, Washington

Di Sioudi BD, Miller CE, Lai K, Grimsley JK, Wild JR (1999) Rational design of organophosphorus hydrolase for altered substrate specificities. Chem Biol Interact 119-120:211-223

Dubey V, Gupta AK, Maiti SN (2002) Mechanism of the diffusion of sulfur mustard, a chemical warfare agent, in butyl and nitrile rubbers. J Polym Sci Pol Phys 40:1821-1827

Dumlao MC, Jeffress LE, Gooding JJ, Donald WA (2016) Solid-phase microextraction low temperature plasma mass spectrometry for the direct and rapid analysis of chemical warfare simulants in complex mixtures. Analyst 141:3714-3721

Faragher WF, Morrel JC, Comay S (1928) Thermal decomposition of organic sulfur compounds. Ind Eng 20:527-538

Giannakoudakis DA, Arcibar-Orozco JA, Bandosz TJ (2016) Effect of GO phase in $\mathrm{Zn}(\mathrm{OH})(2) / \mathrm{GO}$ composite on the extent of photocatalytic reactive adsorption of mustard gas surrogate. Appl Catal B Environ 183:37-46

Glukhovtsev MN, Bach RD (1998) A high-level computational study on the thermochemistry and thermal decomposition of sulphur mustard (2,2'-dichloroethyl sulfide): a chemical warfare agent. J Phys Chem A 102:3438-3446

Graven MW, Weller SW, Peters DL (1966) Catalytic conversion of organophosphate vapor over platinum-alumina. Ind Eng Chem Process Des Dev 5:183-189

Grimsley JK, Singh WP, Wild JR, Giletto A, Novel A (2001) Enzymebased method for the wound-surface removal and decontamination of organophosphorus nerve agents. ACS Symp Ser 792:35-49

Guo X, Yoshinobu J, Yates JT Jr (1990) Decomposition of organophosphonate compound (dimethyl methylphosphonate) on the $\mathrm{Ni}(111)$ and Pd(111) surfaces. J Phys Chem US 94:6839-6842

Guo NLD, Liu J, Dong Z, Zhong J, Kong L (2015) Study on catalytic hydrolysis of sulfur mustard by the haloalkane dehalogenases. Environ Chem 34:1363-1370

Hampton TH, Jackson C, Jung D, Chen CY, Glaholt SP, Stanton BA, Colbourne JK, Shaw JR (2018) Arsenic reduces gene expression response to changing salinity in killifish. Environ Sci Technol 52:8811-8821

Henderson C (2015) The UK government's legal opinion on forcible measures in response to the use of chemical weapons by the Syrian government. Int Comp Law Q 64:179-196

Hill CM, Li W-S, Cheng T-C, DeFrank JJ, Raushel FM (2001) Stereochemical specificity of organophosphorus acid anhydrolase toward $p$-nitrophenyl analogs of soman and sarin. Bioorg Chem 29:27-35

Hirano T, Xu Y, Demura M (2011) Catalytic properties of $\mathrm{Ni}_{3} \mathrm{Al}$ foils for hydrogen production. Adv Mat Res 306:130-133

Hong SB, Raushel FM (1996) Metal-substrate interactions facilitate the catalytic activity of the bacterial phosphotriesterase. Biochemistry 35:10904-10912

Hoskin FCG, Walker JE, Dettbarn WD, Wild JR (1995) Hydrolysis of tetriso by an enzyme derived from Pseudomonas diminuta as a model for the detoxication of O-ethyl S-(2-diisopropylaminoethyl) methylphosphonothiolate (VX). Biochem Pharmacol 49:711-715

Jang JH, Xu Y, Demura M, Wee DM, Hirano T (2011) Catalytic activity improvement of $\mathrm{Ni}_{3} \mathrm{Al}$ foils for methanol decomposition by oxidation-reduction pretreatment. Appl Catal A Gen 398:161-167

Jasenska A, Bartos M, Czernekova V, Rychlik I, Pavlik J, Damborsky J (2002) Cloning and expression of the haloalkane dehalogenase gene dhmA from Mycobacterium avium N85 and preliminary characterization of DhmA. Appl Environ Microbiol 68:3724-3730

Jasenska A, Pavlova M, Strouhal M, Chaloupkova R, Tesinska J, Monincova M, Prokop Z, Bartos M, Pavlik J, Rychlik J, Mobius P, 
Nagata Y, Damborsky J (2005) Cloning, biochemical properties, and distribution of mycobacterial haloalkane dehalogenases. Appl Environ Microbiol 71:6736-6745

Johnson-Winegar A (2001) The US Chemical Demilitarization Program, Statement before the Senate Armed Services Committee, Sub-Committee on Emerging Threats and Capabilities, US Senate 12 July 2001

Jóźwik P (2010) Military application of micro, ultra and nanocrystalline alloys $\mathrm{Ni}_{3} \mathrm{Al}$-technology demonstrator of thermoactive elements for contaminated air treatment systems. Final report of research project OR00004905, WAT, Warszawa

Jozwik P, Salerno M, Stępniowski WJ, Bojar Z, Krawczyk K (2014) Decomposition of cyclohexane on $\mathrm{Ni}_{3} \mathrm{Al}$ thin foil intermetallic catalyst. Materials 7:7039-7047

Jóźwik P, Bojar Z, Winiarek P (2010) Catalytic activity of $\mathrm{Ni}_{3} \mathrm{Al}$ foils in decomposition of selected chemical compounds. Inż Mater 31:654-657

Jóźwik P, Karcz M, Badur J (2011) Numerical modeling of a microreactor for thermocatalytic decomposition of toxic compounds. Chem Process Eng Inz 32:215-227

Khabiri M, Minofar B, Brezovský J, Damborský J, Ettrich R (2013) Interaction of organic solvents with protein structures at proteinsolvent interface. J Mol Model 19:4701-4711

Kiselev A, Mattson A, Andersson M, Palmqvist AEC, Osterlund L (2006) Adsorption and photocatalytic degradation of diisopropyl fluorophosphate and dimethyl methylphosphonate over dry and wet rutile $\mathrm{TiO}_{2}$. J Photochem Photobiol A Chem 184:125-134

Kozlova EA, Vorontsov AV (2006) Noble metal and sulfuric acid modified $\mathrm{TiO}_{2}$ photocatalysts: mineralization of organophosphorous compounds. Appl Catal B Environ 63(1-2):114-123

Ledgard J (2012) The preparatory manual of CWAs, 3rd edn. ISBN: 978-0578-10478-2, USA

Lee KY, Houalla M, Hercules DM, Hall WK (1994) Catalytic oxidative decomposition of dimethyl methylphosphonate over $\mathrm{Cu}$-substituted hydroxyapatite. J Catal 145:223-231

Li Q, Hirata Y, Piao S, Minami M (2000) The by-products generated during sarin synthesis in the Tokyo sarin disaster induced inhibition of natural killer and cytotoxic T lymphocyte activity. Toxicology 146:209-220

Li Z, Hu Z, Cao P, Zhao H (2014) Decontamination of 2-chloroethyl ethyl sulfide by pulsed corona plasma. Plasma Sci Technol 16:1054-1058

Liu J, Powell KL, Thames HD, MacLeod MC (2010) Detoxication of sulfur half-mustards by nucleophilic scavengers: robust activity of thiopurines. Chem Res Toxicol 23(3):488-496

Liu Y, Howarth AJ, Hupp JT, Farha OK (2015) Selective photooxidation of a mustard-gas simulant catalyzed by a porphyrinic metalorganic framework. Angew Chem Int Edit 54:9001-9005

Ma S, Zhou J, Kang YC, Reddic JE, Chen DA (2000) Dimethyl methylphosphonate decomposition on $\mathrm{Cu}$ surfaces: supported $\mathrm{Cu}$ nanoclusters and films on $\mathrm{TiO}_{2}$ (110). Langmuir 20:9686-9694

Malhotra RC, Gaesan K, Sugendran K, Swamy RV (1999) Chemistry and toxicology of sulphur mustard-a review. Def Sci J 49:97-116

Marrs TT, Maynard RL, Sidell F (2007) Chemical warfare agents: toxicology and treatment, 2nd edn. Wiley, Chichester

Mattsson A, Lejon C, Stengl V, Bakardjieva S, Oplustil F, Andersson PO, Osterlund L (2009) Photodegradation of DMMP and CEES on zirconium doped titania nanoparticles. Appl Catal B Environ 92:401-410

Mazur A (1946) An enzyme in animal tissues capable of hydrolyzing the phosphorus-fluorine bond of alkyl fluorophosphates. J Biol Chem 164:271-289

Mazurek M, Witkiewicz Z, Popiel S, Sliwakowski M (2001) Capillary gas chromatography-atomic emission spectroscopy-mass spectrometry analysis of sulphur mustard and transformation products in a block recovered from the Baltic Sea. J Chromatogr A 919:133-145

McDaniel CS, McDaniel J, Wales ME, Wild JR (2006) Enzyme-based additives for paints and coatings. Prog Org Coat 55:182-188

Mitchell BL, Billingsley BG, Logue BA (2014) Evaluation of activated carbon respirator filter effectiveness by concentration mapping of dimethyl methylphosphonate. Int J Environ Heal R 24:5566-5585

Moss JA, Szczepankiewicz SH, Park E, Hoffmann MR (2005) Adsorption and photodegradation of dimethyl methylphosphonate vapor at $\mathrm{Tio}_{2}$ surfaces. J Phys Chem B 109:19779-19785

National Research Council (1984) Committee on demilitarizing chemical munitions and agents. Disposal of Chemical Munitions and Agents, National Academy Press, Washington

National Research Council (1996) Committee on review and evaluation of the army chemical stockpile disposal program, review of systematization of the Tooele chemical agent disposal facility, National Academy Press, Washington, Appendix B

Nawała J, Czupryński K, Popiel S, Dziedzic D, Bełdowski J (2016) Development of the HS-SPME-GC-MS/MS method for analysis of chemical warfare agent and their degradation products in environmental samples. Anal Chim Acta 993:103-116

Neat S, Pârvulescua VI, Epure G, Petrea N, Somoghi V, Ricchiardi G, Bordiga S, Zecchina A (2009) $\mathrm{M} / \mathrm{TiO}_{2} / \mathrm{SiO}_{2}(\mathrm{M}=\mathrm{Fe}, \mathrm{Mn}$, and V) catalysts in photo-decomposition of sulfur mustard. Appl Catal B Environ 91:546-553

Neatu S, Parvulescu VI, Epure G, Preda E, Somoghi V, Damin A, Bordigac S, Zecchina A (2008) Photo-degradation of yperite over V, $\mathrm{Fe}$ and Mn-doped titania-silica photocatalysts. Phys Chem Chem Phys 10:6562-6570

Okumura T, Hisaoka T, Yamada A, Naito T, Isonuma H, Okumura S, Miura K, Sakurada M, Maekawa H, Ishimatsu S, Takasu N, Suzuki K (2005) The Tokyo subway sarin attack-lessons learned. Toxicol Appl Pharm 207:S471-S476

Omburo GA, Kuo JM, Mullins LS, Raushel FM (1992) Characterization of the zinc binding site of bacterial phosphotriesterase. J Biol Chem 267:13278-13283

Osterlund L, Stengl V, Mattsson A, Bakardjieva S, Andersson PO, Oplustil F (2009) Effect of sample preparation and humidity on the photodegradation rate of CEES on pure and $\mathrm{Zn}$ doped anatase $\mathrm{TiO}_{2}$ nanoparticles prepared by homogeneous hydrolysis. Appl Catal B Environ 88:194-203

Panayotov DA, Morris JR (2008) Catalytic degradation of a chemical warfare agent symulant: reaction mechanisms on $\mathrm{TiO}_{2}$-supported Au nanoparticles. J Phys Chem C 112:7496-7502

Panayotov DA, Morris JR (2009) Uptake of a chemical warfare agent simulant (DMMP) on $\mathrm{TiO}_{2}$ : reactive adsorption and active site poisoning. Langmuir 25:3652-3658

Pearson SG, Magee RS (2002) Critical evaluation of proven chemical weapon destruction technologies. IUPAC technical report, University of Bradford, Bradford, West Yorkshire, UK, vol 4, pp 187-316

Petrov V, Trubachev A, Lipanov AM (2006) Analysis of technologies for lewisite destruction. NATO ASI Ser C2006:289-296

Popiel S, Nawała J (2013) Detoxification of sulfur mustard by enzymecatalyzed oxidation using chloroperoxidase. Enzyme Microb Tech 53:295-301

Popiel S, Witkiewicz Z, Szewczuk A (2005) The GC/AED studies on the reactions of sulfur mustard with oxidants. J Hazard Mater B123:94-111

Popiel S, Nawala J, Sankowska M, Witkiewicz Z, Bernat P (2010) Enzymy jako katalizatory rozkładu bojowych środków trujących. Przem Chem 89:1361-1369

Popiel S, Nawała J, Czupryński K (2014a) Preparation and application of sol-gel acrylate and methacrylate solid-phase microextraction 
fibres for gas chromatographic analysis of organoarsenic compounds. Anal Chim Acta 837:52-63

Popiel S, Nawała J, Dziedzic D, Söderstrom M, Vanninen P (2014b) Determination of mustard gas hydrolysis products thiodiglycol and thiodiglycol sulfoxide by gas chromatography-tandem mass spectrometry after trifluoroacetylation. Anal Chem 86:5865-5872

Powroźnik P, Jakubik W, Kazmierczak-Bałata A (2015) Detection of organophosphorus (DMMP) vapour using phthalocyanine-palladium bilayer structures. Procedia Eng 120:368-371

Ramacharyulu PVRK, Praveen KJ, Prasad GK, Sreedhar B (2014) Sulphur doped nano $\mathrm{TiO}_{2}$ : synthesis, characterization and photocatalytic degradation of a toxic chemical in presence of sunlight. Mater Chem Phys 148:692-698

Rastogi VK, DeFrank JJ, Cheng T, Wild JR (1997) Enzymatic hydrolysis of Russian-VX by organophosphorus hydrolase. Biochem Biophys Res Commun 241:294-296

Ratliff JS, Tenney SA, Hu X, Conner SF, Ma S, Chen DA (2009) Decomposition of dimethyl methylphosphonate on $\mathrm{Pt}, \mathrm{Au}$, and $\mathrm{Au}-\mathrm{Pt}$ clusters supported on $\mathrm{TiO}_{2}$ (110). Langmuir 25:216-225

Review and Evaluation of the Army Chemical Stockpile Disposal Program (1996) Review of Systematization of the Tooele Chemical Agent Disposal Facility. The National Academies Press, Washington

Rezanka T, Sigler K (2008) Biologically active compounds of semimetals. Phytochemistry 69:585-606

Rusu CN, Yates JT (2000) Photooxidation of dimethyl methylphosphonate on $\mathrm{TiO}_{2}$ powder. J Phys Chem B 104:12299-12305

Schecter WP, Fry DE (2005) The surgeon and acts of civilian terrorism: chemical agents. J Am Coll Surg 200:128-135

Segal SR, Suib SL, Tang X, Satyapal S (1999) Photoassisted decomposition of dimethyl methylphosphonate over amorphous manganese oxide catalysts. Chem Mater 11:1687-1695

Segal SR, Cao L, Suib SL, Tang X, Satyapal S (2001) Thermal decomposition of dimethyl methylphosphonate over manganese oxide catalysts. J Catal 198:66-76

Shah M, Park AR, Zhang K, Park JH, Yoo PJ (2012) Green synthesis of biphasic $\mathrm{TiO}_{2}$-reduced graphene oxide nanocomposites with highly enhanced photocatalytic activity. ACS Appl Mater Interfaces 4:3893-3901

Shen Z, Zhong JY, Han XY, Wang LY, Cui Y, Chen LK, Zheng YC (2016) Decontamination of chemical warfare agents on sensitive equipment materials using $\mathrm{Zr}^{4+}$ and $\mathrm{Ge}^{4+}$ co-doped $\mathrm{TiO}_{2}$ and hydrofluoroether suspension. Chem Eng J 302:111-119

Shen Z, Zhong J-Y, Yang J-C, Cui Y, Zheng H, Wang L-Y, Wang J-L (2018) Decontamination of chemical warfare agents by $\mathrm{Zn}^{2+}$ and $\mathrm{Ge}^{4+}$ co-doped $\mathrm{TiO}_{2}$ nanocrystals at sub-zero temperatures: a solid-state NMR and GC study. Chem Phys Lett 707:31-39

Singh BK, Walker A (2006) Microbial degradation of organophosphorus compounds. FEMS Microbiol Rev 30:428-471

Singh A, Lee Y, Dressick WJ (2004) Self-cleaning fabrics for decontamination of organophosphorous pesticides and related chemical agents. Adv Mater 16:2112-2115

Stengl V, Popelkova D, Vlacil P (2011a) $\mathrm{TiO}_{2}$-graphene nanocomposite as high performace photocatalysts. J Phys Chem C 115:25209-25218

Stengl V, Bludska J, Oplustil F, Nemec T (2011b) Mesoporous titanium-manganese dioxide for sulphur mustard and soman decontamination. Mater Res Bull 46:2050-2056

Stengl V, Grygar TM, Oplustil F, Nemec T (2012) $\mathrm{Ge}^{4+}$ doped $\mathrm{TiO}_{2}$ for stoichiometric degradation of warfare agents. J Hazard Mater 227-228:62-67

Stengl V, Henych J, Vomacka P, Slusna M (2013) Doping of $\mathrm{TiO}_{2}-\mathrm{GO}$ and $\mathrm{TiO}_{2}-\mathrm{rGO}$ with noble metals: synthesis, characterization and photocatalytic performance for azo dye discoloration. Photochem Photobiol 89:1038-1046

The Convention on the Prohibition of the Development, Production, Stockpiling and Use of Chemical Weapons and on their Destruction (the Chemical Weapons Convention or CWC) (1993) United Nations, Geneva 1992, Paris

Thompson TL, Panayotov DA, Yates JT Jr (2004) Adsorption and thermal decomposition of 2-chloroethyl ethyl sulfide on $\mathrm{TiO}_{2}$ surfaces. J Phys Chem B 108:16825-16833

Trubitsyn DA, Vorontsov AV (2005) Experimental study of dimethyl methylphosphonate decomposition over anatase $\mathrm{TiO}_{2}$. J Phys Chem B 109:21884-21892

Verma M, Gupta VK, Dave V, Chandra R, Prasad GK (2015) Synthesis of sputter deposited $\mathrm{CuO}$ nanoparticles and their use for decontamination of 2-chloroethylethyl sulfide (CEES). J Colloid Interface Sci 438:102-109

Verma M, Chandra R, Gupta VK (2016) Decontamination of 2-chloro ethyl ethyl sulphide and dimethyl methyl phosphonate from aqueous solutions using manganese oxide nanostructures. J Mol Liq 215:285-292

Wagner GW, Maciver BK, Rohrbaugh DK, Yang YC (1999) Thermal degradation of bis (2-chloroethyl) sulfide (mustard gas). Phosphorus Sulfur 152:65-76

Wang X-H, Wang Q, Nie Z-W, He L-Y, Sheng X-F (2018) Ralstonia eutropha $\mathrm{Q} 2-8$ reduces wheat plant above-ground tissue cadmium and arsenic uptake and increases the expression of the plant root cell wall organization and biosynthesis-related proteins. Environ Pollut 242:1488-1499

Wolfe-Simon F, Switzer BJ, Kulp TR, Gordon GW, Hoeft SE, PettRidge J, Stolz JF, Webb SM, Weber PK, Davies PC, Anbar AD, Oremland RS (2011) A bacterium that can grow by using arsenic instead of phosphorus. Science 332(6034):1163-1166

Wu S, Lianrong W, Rui G, Tong T, Hao B, Li Z, Du S, Deng Z, Chen S (2018) Signature arsenic detoxification pathways in Holomonas sp. strain GFAJ-1. MBio 9(3):e00515-18

Xue XM, Yan Y, Xu HJ, Wang N, Zhang X, Ye J (2014) ArsH from Synechocystis sp. PCC 6803 reduces chromate and ferric iron. FEMS Microbiol Lett 356:105-112

Yang MQ, Zhang N, Xu YJ (2013a) Synthesis of fullerene-, carbon nanotube-, and graphene- $\mathrm{TiO}_{2}$ nanocomposite photocatalysts for selective oxidation: a comparative study. ACS Appl Mater Interfaces 5:1156-1164

Yang XF, Qin JL, Li Y, Zhang RX, Tang H (2013b) Graphene-spindle shaped $\mathrm{TiO}_{2}$ mesocrystal composites: facile synthesis and enhanced visible light photocatalytic performance. J Hazard Mater 261:342-350

Ye J, Yang HC, Rosen BP, Bhattacharjee H (2007) Crystal structure of the flavoprotein ArsH from Sinorhizobium meliloti. FEBS Lett 581:3996-4000

Yeung DT, Smith JR, Sweeney RE, Lenz DE, Cerasoli DM (2007) Direct detection of stereospecific soman hydrolysis by wild-type human serum paraoxonase. FEBS J 274:1183-1191

Zhang X, Wu R, Song L, Lin M, Cao Z, Wu W, Mo Y (2009) Molecular dynamics simulations of the detoxification of paraoxon catalyzed by phosphotriesterase. J Comput Chem 30:2388-2401

Zhao Y-Z, Guo X, Zhong J-Y, Guo N, Chen L-C, Dong Z-Y (2018) Characterization of FM2382 from Fulvimarina manganoxydans sp. Nov. 8047 with potential enzymatic decontamination of sulfur mustard. Protein Expr Purif 141:63-70

Zhou J, Chen DA (2003) Controlling size distributions of copper islands grown on $\mathrm{TiO}_{2}(110)-(1 \times 2)$. Surf Sci 527:183-197

Zuo GM, Cheng ZX, Li GW, Shi WP, Miao T (2007) Study on photolytic and photocatalytic decontamination of air polluted by chemical warfare agents (CWAs). Chem Eng J 128:135-140 